\title{
$\mathrm{C}|\mathrm{E}| \mathrm{D}|\mathrm{L}| \mathrm{A} \mid \mathrm{S}$
}

Centro de Estudios

Distributivos, Laborales y Sociales

Maestría en Economía

Universidad Nacional de La Plata

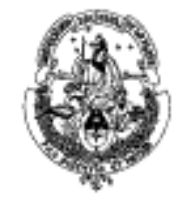

\section{International Market Access and Poverty in Argentina}

\author{
Guido Porto
}

Documento de Trabajo Nro. 96

Abril, 2010 
REVIEW OF INTERNATIONAL ECONOMICS

Manuscript No: \# 7057, Acceptance Date: 4 February 2009

International Market Access and Poverty in Argentina

Guido Porto

RRH: MARKET ACCESS AND POVERTY IN ARGENTINA

LRH: Guido Porto

Abstract

This paper examines the impact of access to international agro-manufacture markets on poverty in Argentina. Estimates from the literature suggest that expanded market access would cause the international price of Argentine exports of agro-manufactures to increase by between 8.7 and 15.9 percent. I explore two poverty e ects caused by these prices changes: on food expenditure and on wages. Using a household budget survey, I estimate the impact of higher food prices on the Argentine poverty line. Using a labor force survey, I estimate the responses of wages to changes in export prices. My main nding is that market access would cause poverty to decline in Argentina. From a national head count of 29.26 percent, the poverty rate would decline to between 28.28 and 28.80 percent. This means that between 131,000 and 343,000 Argentines would be moved out of poverty.

Porto: Development Research Group, The World Bank, MailStop MC3-303, 1818 H Street, Washington, DC, 20433. Te: +54-221-424-1262, email: gporto@worldbank.org. I wish to thank I. Brambilla, B. Hoekman, A. Nicita, M. Olarreaga, and I. Soloaga for very valuable comments. I have bene tted from suggestions and comments of seminar participants at Universidad Di Tella, Universidad de La Plata, and the LACEA (Latin America and Caribbean Economic Association) Meetings. All errors are my responsibility.

JEL codes: F14F16F17

Number of Figures: 0 Number of Tables: 4

Date: February 18, 2009

Address of Contact Author: Guido Porto, Calle 10 \#961, La Plata (1900), Argentina. Phone: +54-221-424-1262, email: gporto@worldbank.org 


\section{Introduction}

This paper investigates the poverty impacts, in developing countries, of agricultural trade reforms in the developed world. The reforms that I explore here are related to the ongoing discussion at the Doha Round that seeks to eliminate agricultural protection in international markets. Speci cally, developed countries are expected to reduce subsidies, tari sand non-tari barriers on cereals and agricultural manufactures (dairy products, beef, oils). As a result, the international prices of these goods are expected to increase In a typical developing country, there will be two measurable poverty e ects: on the poverty line, through changes in the prices of consumption goods, and on household income, through changes in factor prices. On the expenditure side, foreign trade policies a ect international and domestic prices of agricultural and agro-manufactured goods and thus the expenditure needed to purchase the poverty bundle (particularly in food). On the income side, the price changes faced by producers cause changes in relative factor demands and in relative factor prices and thus in household labor income In the end, poverty is a ected. Some households may be moved out of poverty and some others may be moved into poverty depending upon the induced changes in wages and the induced changes in food prices. Di erent developing countries will be a ected in di erent ways: while net food importers will likely be hurt by lower protection in agriculture, net producers will be bene ted. In this paper, I illustrate the nature of these poverty impacts in Argentina, a country with a clear comparative advantage in agriculture. This case study is thus relevant because if any positive e ects from the Doha Development Agenda are expected, they are bound to show up in countries like Argentina.

My estimation of the poverty impacts of the enhanced agricultural export markets comprises three steps. Since the main consequence of trade liberalization is greater international market 
access for Argentine products, in the rst step I calculate the changes in the prices of agro-manufactured exports caused by foreign trade reforms in the developed world. In the second step, I assess the change in the real income of the average Argentine worker. To do this, I estimate wage price-elasticities (measuring the responses of wages to price changes) and I update the poverty line. Finally, in the third step, I use the policy-induced price changes, the estimated wage price-elasticities and the shift in the poverty line to predict the real income that would hypothetically be earned by each Argentine household after the trade reforms. To study the poverty impacts, I compute pre and post-policy head-count ratios (i.e, the proportion of the population with an income lower than the poverty line).

The main nding of this paper is that agricultural market access would cause poverty to decline in Argentina. Based on estimates reported in the related literature, I establish that agricultural trade liberalization is indeed associated with increases in the prices of agro-manufactured Argentine exports. This leads to a higher poverty line, which tends to increase poverty, and to higher wages and household income, which tends to decrease poverty. In Argentina, the impacts on wages and income are larger than the impacts on consumption prices. As a result, the net e ect of trade liberalization is poverty-reducing. From a national head count of 29.26 percent in 1998, the poverty rate would decline to between 28.28 and 28.80 percent. Poverty would drop nationwide, with larger declines observed in initially poorer regions. 


\section{Poverty in Argentina}

The poverty measure used in this paper is the head count ratio, $\mathrm{HC}$, de ned as the fraction of the population with an income below the poverty line z. Letting HC stand for the head count,

I de ne $H C=\frac{1}{N}^{P}, \operatorname{lf} \ln \left(y^{i}\right)<\ln (z) g$, where $N$ is total population, $y^{i}$ is income, and $\operatorname{lfg}$ is an indicator function that takes the value of one if the argument within brackets is true. The poverty line $z$ is the level of income needed to purchase the poverty consumption basket, which includes food items that satisfy a minimum caloric and energetic intake, and non-food essential items (clothing, housing, health and education). The poverty line is measured so as to account for the di erent caloric requirements of individuals with di erent characteristics, such as sex and age This means that $z$ and individual income, $y^{i}$, are measured in per equivalent adult units (Deaton, 1997). In Argentina, the National Institute of Statistics and Census (INDEC) constructs poverty lines and per equivalent adult scales (INDEC 2002).

At the national leve, the poverty rate in Argentina in 1998 was 29.26 percent. ${ }^{1}$ There are substantial regional di erences in the country, both in the poverty rate and in the distribution of income The head count was 23.3 percent in Greater Buenos Aires, 27.3 percent in Pampa, 36.4 percent in Northeast, 40.6 percent in Northwest, 27.5 percent in Cuyo, and 18.3 percent in Patagonia.

\section{Theory: Poverty Impacts}

The poverty analysis requires a comparison of the proportion of individuals in poverty before and after the simulated foreign policy reform. Given a poverty line $z$, the head count ratio is given by $F(z)$, where $F()$ is the observed cumulative distribution function of income before 
the trade reform. Let $\mathbb{E}()$ be the cumulative distribution function of the post-reform income and let $\mathbb{E}$ be the updated poverty line The post policy head count ratio is therefore $\mathbb{E}(\mathbb{E})$. Accordingly, a trade reform lowers poverty if $F(z) \quad F(z)$.

To see the di erent channels through which trade a ects poverty, it is convenient to de ne $\mathbb{Z}$

the head count as HC $=f(y) d y$, where $f()$ is the density of per equivalent adult income

associated with $\mathrm{F}\left(\mathrm{)}\right.$. Let ${ }^{0}$ be the policy parameter that represents the level of protection on agro-manufactured products in developed countries. Di erentiating HC with respect to , I get

$$
\frac{@}{@} H C=f(z) \frac{@}{@}+{ }_{0}^{\mathbb{Z}} @ \frac{@}{@} f(y) d y:
$$

A change in trade policy ( ) has two e ects on poverty: a change in the poverty line and a shift in the distribution of income. Details follow.

\subsection{Changes in the Poverty Line}

The rst term on the right hand side of (1) measures the impact of a foreign trade reform on the poverty line: a change in a ects consumer prices and therefore the cost of purchasing the poverty bundle. Assuming the poverty line $z$ increases by $@=@$, $f(z)$ is a measure of the increase in the head count ratio (conditional on a given density). For a trade reform that increases Argentine export prices, this e ect will be positive (i.e, poverty-increasing).

In general, the poverty bundle comprises both food and nonfood items. The identi cation of a bundle of food items that would allow di erent individuals to achieve a minimum caloric intake de nes the indigence line (or extreme poverty line). This is the amount of money needed 
to purchase these minimum calories. To determine the poverty line, expenses on basic non-food items, such as clothing, health, education, etc., are added. The poverty line can thus be de ned as $z={ }_{g}^{X} p_{g} q_{g}$, where $p_{g}$ is the price of good $g$, and $q_{g}$ is the quantity determined in the construction of the poverty line Holding the required quantities constant, the change in the (log) poverty line caused by a change in the price of good $g$ is given by

$$
\ln z=g \ln p_{g}(\quad)
$$

where $g$ is the weight attached to good g. In deriving these changes in the poverty line, I made two implicit assumptions. First, I kept the quantities consumed constant. This corresponds to a rst order approximation to the true change in welfare, as in Deaton (1997). Second, I do not allow changes in the prices of non-tradable goods to adjust (See Porto, 2006).

\subsection{Shifts in the Distribution of Income}

The second poverty impact of a change in foreign trade policy is given by the shift in the distribution of income. To see this, let the total income of household $h$ be $Y^{h}={ }_{m}^{X} w_{m}^{h}+k^{h}$, where $w_{m}^{h}$ is the wage earned by household member $m$ (head and non-head), and $k^{h}$ is non-labor income, including pro ts, returns to speci c factors and transfers.

Argentina is a highly urbanized country (over 85 percent of the population lives in urban areas). Further, the survey data that I use in the empirical section captures employment in urban areas only. For these reasons, in the rest of the paper, I focus on the e ects of trade on wages $w_{m}^{h}$. In particular, I am not able to study impacts in rural areas, return to land or farm pro ts. In addition, I do not consider the role of $\mathrm{k}^{\mathrm{h}}$ because non-labor income is very badly 
measured in the data. The proportional changes in the total income of household $\mathrm{h}$ is given by

$$
\frac{d Y^{h}}{Y^{h}}={ }_{m}^{X}{ }_{m}^{h "} w_{m}^{h} \frac{@ n p_{a}}{@} d ;
$$

where $" w_{m}^{h}$ is the elasticity of the wage earned by member $m$ in household $h$ with respect to the price $p_{a}$, and $\underset{m}{h}$ is the share of the labor income of the member $m$ in total household income ${ }^{2}$ In a small open economy, there is a theoretical general equilibrium relationship between traded good prices and factor prices. In a two-good, two-factor mode, this relationship is established in the Stolper-Samuelson theorem: an increase in the relative price of a traded good causes a more than proportional increase in the price of the factor intensively used in its production. For multidimensional models, it is only possible to predict correlations between movements in factor prices and movements in product prices (Dixit and Norman, 1980). Similar caveats apply when factor supplies are endogenous (Dixit and Norman, 1980). Learning the signs and magnitudes of these correlations becomes an empirical question and I deal with this in section 4 below.

For a policy change from to e , the change in the income of household $\mathrm{h}$ can be estimated with

$$
b_{y^{h}=Y^{h}} \underset{m}{{ }_{m}^{h} b_{w_{m}^{h}}} \quad b \ln p_{a}(; e) ;
$$

where $\mathrm{b} \ln p_{a}($; e $)$ is the predicted change in the price of agro-manufactured exports that is caused by the change in policy, and $\mathrm{b}_{w_{m}^{h}}$ is the estimated wage price-elasticity. 


\section{Estimation}

Conceptually, there are threelinks in the methodology that I use in this paper. The initial step is a trade shock, i.e., a foreign trade reform, which causes a change in the domestic prices of agro-manufactured exports in Argentina. The second step is the response of the labor income of Argentine households and the updating of the poverty line. The third step comprises the poverty impacts (comparing before and after head count ratios).

\subsection{Changes in the Prices of Agro-M anufactured Exports}

I begin with the changes in the international prices of typical agro-manufactured exports of Argentina, such as dairy, beef, oils and fats, and mills products. I assume that Argentina is a small open economy that faces exogenously given prices for these goods. ${ }^{3}$ Thus, the domestic price of agro-manufactured exports is $p_{a}=p_{a}(\quad)$, where $p_{a}$ is the international price of these goods. The trade policy parameter is determined by the level of tari and non-tari protection, production support and export subsidies in large developed economies. By any standards, is high. Indeed, Argentina has al ways faced highly distorted markets for agro-manufactured products. For most of these goods, trade intervention takes the form of a tari rate quota, which is a two-tier tari structure. Argentina is assigned a quota and imports of goods within this quota pay a relatively low tari . Out of quota imports are subject to much higher and often times prohibitive tari s. There are also a number of non-tari barriers, such as standards, technical barriers, as well as subsidies to domestic production and exports. All these policies cause international prices to decline and restrict the market access of Argentine products.

To provide some evidence on the value of , I use the OECD (2000) methodology that 
produces thetari equivalent of ad-valorem tari son in-quota imports, of tari s on out-of-quota imports, and of speci c tari s. In 1999, for example, the average tari on agro-manufactured goods was 6.4 percent in the United State, 18.1 percent in Canada and 21.3 percent in the European Union. ${ }^{4}$ The extensive subsidies to production and exports in many developed countries produce even larger distortions.

What magnitudes of price changes can be expected after episodes of trade liberalization (both tari and subsidy cuts) in the developed world? Instead of setting up an empirical model of price changes (which would be beyond the scope of this paper), I use estimates from the available literature. There are essentially two polar approaches that can be used to estimate price changes: to recover demand and supply elasticities from the data, or to cal ibrate CGE models. The elasticity methodology is based on the econometric estimation of structural parameters and it is very data intensive The CGE modeling, in contrast, relies more on modeling assumptions but allows for a more thorough computation of economic responses. For my purposes, I use empirical ndings on these two strands of literature to de ne a lower and an upper bound for the price changes. ${ }^{5}$

One recent paper that estimates the responses of equilibrium prices of agricultural products in international markets is Hoekman, $\mathrm{Ng}$, and Olarreaga (2004). The authors estimate the parameters of import demands and export supplies for di erent goods in di erent countries and use these parameters to solve for the equilibrium prices. To calculate the price responses of key exports of agro-manufactured products in Argentina, I combine the estimates from Hoekman et al. with changes in that capture the elimination of tari protection and domestic support (export and production subsidies) in developed countries. The rst column of Table 1 reports these price responses. The largest price increases are observed in Dairy Products (17.8 
percent), Mills Products (17.4 percent), Bef (17.3 percent) and Oils and Fats (8.7 percent). Averaging these individual price changes (weighted by Argentine exports), I get an estimate of the aggregate price change for agricultural manufactured products of 15.9 percent. This de nes the upper bound.

INSERT Table 1 Here

Beghin et al. (2002), on the other hand, perform a CGE study of the responses of the international prices of agro-manufactured goods to a foreign trade reform that, as Hoekman et al., includes the elimination of both trade protection and domestic support. ${ }^{6}$ The second column of Table 1 reports the increase in prices: 10.4 percent in Bef, 9 percent in Sugar, 8.3 percent in Dairy Products, and 2.2 percent in Oils and Fats. The average price change (weighted by Argentine exports) is estimated at 8.7 percent. This de nes the lower bound.

\subsection{U pdating the Poverty Line}

To estimate the change in the poverty lines induced by the above price changes, I need to estimate equation (2). Let $b \ln p_{i}(\quad)$ be the price changes of agro-manufactured product $i$ arising from the foreign trade reforms. The poverty line $z$ can be updated as

$$
b \ln z={ }_{i 2 a}^{x} b_{i} b \ln p_{i}(\quad):
$$

To estimatethe weights, $b_{i}, I$ use budget shares. Sincethe pattern of consumption varies greatly by level of income, rather than using averages across all households, budget shares of households in a neighborhood of the poverty line are needed. Due to small sample problems, however, it is generally necessary to de ne a \reference" group, a set of households with relatively low 
income but that are yet not poor. In practice, I estimate $b_{i}$ with the average budget share spent on di erent agro-manufactures (as in Table 1) by households in the second quintile of the distribution. To account for regional di erences in consumption, I do this separately for each of the six Argentine regions, the Greater Buenos Aires, Pampa, Northeast, Northwest, Cuyo, and Patagonia.

The changes in the regional poverty lines are reported in Table 2. As expected, the induced increase in the export price of agro-manufactured goods causes the poverty line to increase In the lower bound, the highest increases in the poverty lines occur in Northwest and Northeast (3.8 and 3.6 percent, respectively) and the lowest increase is observed in the Greater Buenos Aires (2.8 percent). In the upper bound, the highest increase of 6.8 percent is observed in Northwest and the lowest, 5 percent, in the Greater Buenos Aires.

\section{INSERT Table 2 Here}

\subsection{The Wage Price-Elasticities}

In order to derivethe wage price-elasticities, I begin by laying out a simplemodel that illustrates how factor prices are determined in general equilibrium (see Porto, 2003). Equilibrium wages result from the behavior of workers and rms: Workers supply labor and rms demand labor and the equilibrium wages result from equating the supply and demand wage functions. In a model with constant returns to scale, perfect competition and as many traded goods as factors, wages are fully determined by the prices of the traded goods, which are exogenous (See Dixit and Norman, 1980, for details). Under these assumptions, I can write

$$
w^{j}=w^{j}(p ; \quad ; \quad) ;
$$


where $\mathrm{p}$ is a vector of prices, is a vector of expenditure shifters (such as individual characteristics) and is a vector of pro t shifters (variables that a ect the decisions of rms and technical change). This relationship, which de nes the wage price-elasticities (that is, the response of wages to price changes), can be estimated with data on wages, prices of traded goods, individual characteristics and controls for technical change.

The approach followed here attempts to recover the wage price-elasticities using household surveys as a source of data on individual labor income In Argentina, the necessary data are available in the Permanent Household Survey (Encuesta Permanente de Hogares, EPH). The EPHs are labor market surveys with information on wages, employment, hours worked, and individual and household characteristics.

The main problem with using survey data to estimate the wage price-elasticities is the lack of price data at the level of the household. To deal with this, I exploit the time variation in prices and surveys. In fact, the EPH surveys are gathered in May and October every year, so that sixteen surveys from 1992 to 1999 (two per year) can be used to identify the elasticities. This method adapts techniques generally used in demand analysis (Porto, 2006). Wolak (1996), for instance, estimates a system of demand elasticities using the time variation in CPS surveys in the United States. Similarly, Deaton (1997) develops methods to estimate demand elasticities using regional variation in unit values. On wages, Ravallion (1990) estimates wage responses to food prices in Bangladesh, while Goldberg and Tracy (2003) use CPS wage data and industry speci c exchange rates to estimate the factor income e ects of exchange rate movements.

The relationship between wages and prices in (6) is possibly di erent for di erent types of labor because the response of wages to the same price may depend, in principle, on skill intensities. I de ne three labor factors: unskilled labor (comprising individuals with only 
primary education), semiskilled labor (comprising individuals having completed secondary education), and skilled labor (comprising workers holding college degrees). Let $E^{j}$ be the $1 \times 3 \mathrm{j}^{\text {th }}$ row of a matrix $\mathrm{E}$ of dummy variables for the three educational categories of labor. I capture the di erential impact of prices on the wages of individuals with di erent skills with the following mode

$$
\ln w^{j}=+E^{j} \ln p_{a}^{j}+E^{j}+z^{j 0}+{ }^{j}
$$

where the variable $\ln p_{a}^{j}$ is the logarithm of the international price of agro-manufactured exports published by the Argentine Institute of Statistics and Census. In (7), is the vector of wage-price elasticities, one for each of the three educational categories. The regression model includes the educational categories separately, with parameter vector (the returns to schooling), and a vector $z^{j}$ of individual characteristics like age (and age squared), gender and marital status. Themodel also controls for the prices of non-agricultural exports and of imports of consumption and capital goods. In a given time period, all households face the same prices. The index $\mathrm{j}$ attached to the prices in (7) captures the fact that I work with di erent surveys in time periods with di erent prices. The estimated wage price elasticity for individual $\mathrm{j}$ with respect to price $p_{a}$ is given by $E^{j} b$. The error term is $j^{j}$. Since all households in a given survey sample face the same prices, I correct the estimated standard errors for clustering e ects (Kloek, 1981).

In the model speci ed in (7), equilibrium wages are determined by individual characteristics (to account for the heterogeneity of labor supply) and by a vector of export and import prices (to account for labor demand). In addition, I include time trends in the regressions, interacted 
with the educational dummies, that capture technical change that may a ect wages di erently by skill levels.

Table 3 reports the wage price lasticities obtained from the estimation of (7). To allow for more exibility in the mode, I estimate a di erent wage equation for each of the six regions of the country. Overall, I nd that the prices of exportable agricultural manufactures impact positively on wages for workers of every skill and in every region. In addition, notice that the estimated elasticities do not vary much by skill levels or by regions. For unskilled labor, wages respond by between 0.69 to 0.71 percent in all regions, except in Northeast, where the elasticity is slightly higher, 0.85 . For the case of semiskilled labor, the elasticities vary from 0.57 in Great Buenos Aires to 0.81 in Northeast. Finally, the wages of skilled workers react by a minimum elasticity of 0.41 in Patagonia, to $0.82-0.84$ in Great Buenos Aires and Pampa. The nding that the wages of skilled and unskilled workers react in the same direction to these trade liberalization episodes is perfectly consistent with the theoretical correlations between factor prices and product prices since I do not restrict the model to display Stolper-Samuelson e ects.

INSERT Table 3 Here

The bottom panel of Table 3 reports the coe cients of the time trends, interacted with the educational dummies (so as to measure di erent types of technical change). The trend coe cients are positive and increasing in the skill level. These controls thus capture the increasing inequality in the functional distribution of income, a characteristic feature of the Argentine economy during the 1990s. 


\section{Poverty Impacts}

The poverty analysis follows from a simple simulation: I compare the fraction of the population that lived in poverty in 1998 with the fraction of the population that would be poor after the trade reforms in the developed world. The head count ratio before the reform is simply $F(z)$. The head count ratio after the foreign trade reforms, $\mathbb{E}(\mathbb{E})$; is the proportion of individuals with a simulated per equivalent adult income below the updated poverty line $\mathrm{e}$. There are two such ratios, one for each of the lower and upper bounds for the price changes of agro-manufactured exports. For each bound, I predict the hypothetical income of the household by multiplying the estimated wage priceelasticities (Table 3) with the changes in prices (Table 1), taking into account the share of income derived from wages as in equation (4). I then compare this predicted income with the poverty line $\mathbf{z}$.

Results arelisted in Table4. Panel A displays thepoverty simulations under thelower bound for the price changes and Pane $B$, under the upper bound. The main nding on the paper is that agricultural market access would cause poverty to decline in Argentina (see columns 1 and $4 \mid$ and $5 \mid$ in Table 4). From a national head count of 29.26 percent, the poverty rate would decline to 28.80 percent in the lower bound or to 28.28 percent in the upper bound. This means that between 0.46 and 0.98 percent of the population would be moved out of poverty by a set of foreign trade reforms that raises agro-manufactured export prices. The actual number

of individuals a ected is non-trivial: from 161 thousand, in the lower bound, to 343 thousand Argentines, in the upper bound, would abandon poverty as a result of higher market access.

INSERT Table 4 Here

Table 4 reports a decomposition of these aggregate poverty changes into the two main 
impacts described in section 3: the right shift in the poverty line and the right shift in the distribution of income. The trade reforms generated in the developed world imply higher prices of consumption goods and thus lead to a higher poverty line and to higher poverty (column 2). Instead, higher prices of agro-manufactured export goods cause wages to increase and thus lead to higher income and lower poverty (column 3). In the case of Argentina, a country with a clear comparative advantagein agro-manufactures, poverty would declinein theend (column 4). Notice, however, that results may be di erent in countries that are net importers of these goods (so that the adjustment of the poverty line would produce larger impacts than the adjustment of nominal wage income).

Poverty would decline in all regions. The largest poverty declines would be observed in Northeast and Cuyo: in the lower bound for price changes, the head count would decrease by 0.70-0.86 percentage points; in the upper bound, the reductions in the head count would be of 1.62 and 1.23 percentage points, respectively. In Pampa, Northwest, and Greater Buenos Aires, the decline in poverty would be mild, around 0.30 percentage points in the lower bound, and between 0.63 and 0.93 in the upper bound. Poverty alleviation would be lowest in Patagonia, the regions with the lowest initial head counts.

The intuition for these results is straightforward. On average, labor income would react more than consumer prices. As a result, the real income of households near the poverty lines would increase and the head count would decrease. To understand the regional pattern of changes in the poverty count, notice that, rst, there are only small di erences in the changed in the regional poverty lines, but, second, that unskilled labor is more abundant in regions like Northeast, Northwest and Cuyo. Since unskilled workers are more likely to be poor in the rst place, poverty alleviation is expected to take place more prominently among these households. 


\section{Conclusions}

This paper has examined the poverty impacts of increased agricultural market access for Argentine exports. Market access could be secured by a set of foreign agricultural trade policies, such as the elimination of agricultural subsidies, trade tari s, and non-tari barriers. In this paper, market access is measured by estimating the response of the international price of agro-manufactured exports to such trade reforms.

Based on estimates from the available literature, a lower and an upper bound for the price responses have been adopted. These price changes have two measurable e ects on Argentine households: an e ect on consumer prices of food items, and an e ect on wages. Higher prices of agro-manufactured exports would make the food basket more expensive, which works towards

increases in poverty, but would boost labor demand and wages, which works towards poverty alleviation. In the end, I have found that the labor incomee ect is higher than the poverty line e ect, and poverty would decrease as a result (by between 0.46 and 0.98 percentage points).

It is often been argued that market access to international agricultural market would improve living conditions in developing countries. Onelesson from this paper is that this argument is not necessarily true since higher household income can be outweighed by higher consumer prices. This nding is consistent with the claim that, in the presence of agricultural tradeliberalization, net food exporters like Argentina stand to win, while net food importers lose. In Argentina, a country with a clear comparative advantage in agriculture, I have found that the poverty impacts are important but perhaps not as large as a priori expected. 


\section{R eferences}

Anderson, Kym and William Martin (eds.), Agricultural Trade Reform and the Doha Development Agenda, London: Palgrave Macmillan and Washington DC: World Bank, 2006.

Beghin, John C., David Roland-Holst and Dominique van der Mensbrugghe, IGlobal Agriculture Trade and the Doha Round: What are the Implications for North and South?," Working Paper 02-WP 308, Center for Agricultural and Rural Development, lowa State University, 2002.

Brambilla, Irene, Sebastian Galiani, and Guido Porto, \Anti-Export Bias and Import Substitution in the Recent History of Trade Policy in Argentina," manuscript JFK School of Government, Harvard University, 2009.

Deaton, Angus, The Analysis of Household Surveys. A Microeconometric Approach to Development Policy, Washington DC: J ohn Hopkins University Press, 1997.

Dixit, Avinash and Victor Norman, Theory of International Trade. A Dual, General Equilibrium Approach, Cambridge: Cambridge Economic Handbooks, 1980.

Goldberg, Linda and J oseph Tracy, \Exchange Rates and Wages," Federal Reserve Bank of New York, manuscript, 2003.

Hertel, Thomas and L. Alan Winters (eds.), Poverty and the WTO: Impacts of the Doha Development Round, Washington DC: Palgrave Macmillan, 2007.

Hoekman, Bernard, Francis Ng and Marcelo Olarreaga, \Agricultural Tari s or Subsidies: Which Are More Important for Developing Countries?" World Bank Economic Review 19 (2004):205-236. 
INDEC (2002). IIncidencia de la Pobreza y de la Indigencia en los Aglomerados Urbanos," Press release, Buenos Aires, Argentina.

Kloek, T., \OLS Estimation in a Model Where a Microvariable is Explained by Aggregates and Contemporaneous Disturbances are Equicorrelated," Econometrica 49 (1981):205-207.

McKenzie, David, \Aggregate Shocks and Urban Labor Market Responses: Evidence From Argentina's Financial Crisis," Economic Development and Cultural Change 52 (2004):719-758.

Nicita, Alessandro, IWho Bene ted from Trade Liberalization in Mexico?," J ournal of Development Economics (2009, forthcoming).

OECD (2000). \ Post Uruguay Rounds Tari Regimes," Paris: OECD.

Porto, Guido, ITrade Reforms, Market Access and Poverty in Argentina," Policy Research Working Paper No 3135, World Bank, Washington DC, 2003.

Porto, Guido, I Using Survey Data to Assess the Distributional E ects of TradePolicy," J ournal of International Economics 70 (2006):140-160.

Ravallion, Martin, \Rural Welfare E ects of Food Price Changes Under Induced Wage Responses: Theory and Evidencefor Bangladesh," Oxford Economic Papers 42 (1990): 574-585.

Wolak, Frank A., IThe Welfare Impacts of Competitive Telecommunications Supply: A Household-Level Analysis," Brookings Papers on Economic Activity Microeconomics, 1996, pp. 269-340. 


\section{Notes}

${ }^{1}$ The baseline period to carry out the poverty simulations is October 1998. This choice allows me to abstract from the impacts of the 2001 crisis. My analysis is not about poverty and the recent nancial crisis in Argentina; see Mckenzie (2004) and his references for studies on this topic. My objective is to simulate a trade policy reform along the lines of the WTO Doha Round negotiations.

${ }^{2}$ To simplify the analysis, I assume that there is no change in unemployment and I do not measure the impacts of changes in scal revenue via trade taxes.

${ }^{3}$ Since Argentina has a clear comparative advantage in primary products and in agro-manufactures, I focus on export prices rather than on import prices. The share of agro-manufactures in total exports is around 17 percent in the 2000s; the share of food imports is instead close to 3 percent. See Brambilla, Galiani, and Porto (2009).

${ }^{4}$ The average tari on Meat is low in the United States, around 2.7 percent, but it is high in Canada and the European Union, around 23.5 percent and 55.9 percent, respectively. Dairy Products (chapter 4) face an average tari of 8.3 percent in the U.S., 190.3 percent in Canada, and 55.2 percent in the E.U. Imports of Oils and Fats (chapter 15) are subject to an average tari of 4.9 percent in the U.S., 10.2 percent in Canada and 15.5 percent in the E.U.

${ }^{5}$ In this paper, I assume that the change in international prices is fully transmitted to the domestic economy. See Nicita (2009) for an attempt to introduce imperfect pass-through in measuring the welfare impacts of trade liberalization.

${ }^{6}$ The CGE literature on price changes from agricultural liberalization is large. I adopt the price changes in Beghin et al. (2002) because they deal with global comprehensive agricultural reforms rather than the more limited reforms of the recent Doha Development Agenda (see Hertel and Winters, 2007; Anderson and Martin, 2006). 


\begin{tabular}{|c|c|c|}
\hline & \multicolumn{2}{|c|}{ Price Changes } \\
\hline & $\begin{array}{c}\text { Econometric } \\
\text { Estimation }\end{array}$ & CGE \\
\hline Oils and Fats & 8.7 & 2.2 \\
\hline Beff & 17.3 & 10.4 \\
\hline Dairy Products & 17.8 & 8.3 \\
\hline Beverages & 14.7 & - \\
\hline Mills Products & 17.4 & - \\
\hline Sugar & 16.4 & 9.0 \\
\hline Average & 15.9 & 8.7 \\
\hline $\begin{array}{l}\text { Notes: percentage } \\
\text { caused by a reforr } \\
\text { protection and all do } \\
\text { in developed countrie } \\
\text { (2) Beghin et al. (200 }\end{array}$ & $\begin{array}{l}\text { gge in internat } \\
\text { that eliminate } \\
\text { stic support on } \\
\text { (1) Hoekman et }\end{array}$ & $\begin{array}{l}\text { hal price } \\
\text { all tari } \\
\text { gricultur } \\
\text { l. (2004) }\end{array}$ \\
\hline
\end{tabular}

Table 1. Estimated Changes in International Prices of Agricultural Products 


\begin{tabular}{lccccc}
\hline \hline & \multicolumn{5}{c}{ Poverty Lines } \\
\cline { 2 - 6 } & $\begin{array}{c}\text { before } \\
(1)\end{array}$ & $\begin{array}{c}\text { lower bound } \\
(2)\end{array}$ & $\begin{array}{c}\text { increase } \\
\text { (\%) }\end{array}$ & $\begin{array}{c}\text { upper bound } \\
\text { (3) }\end{array}$ & $\begin{array}{c}\text { increase } \\
(\%)\end{array}$ \\
\hline Great Buenos Aires & 5.083 & 5.111 & 2.8 & 5.133 & 5.0 \\
Pampa & 4.983 & 5.015 & 3.2 & 5.039 & 5.6 \\
NorthEast & 4.961 & 4.997 & 3.6 & 5.022 & 6.1 \\
NorthWest & 4.936 & 4.974 & 3.8 & 5.004 & 6.8 \\
Cuyo & 4.946 & 4.977 & 3.1 & 5.000 & 5.4 \\
Patagonia & 5.031 & 5.061 & 3.0 & 5.083 & 5.2 \\
\hline \hline
\end{tabular}

Notes. (1): average budget of households in the second quintile (Household Expenditure Survey).

(2): poverty lines (in logs) as of October 1998 (Indec, 2002).

(3): updated poverty lines (in logs) induced by the lower bound price change.

(4): updated poverty lines (in logs) induced by the upper bound price change.

Table 2. Changes in the Poverty Lines 


\begin{tabular}{lcclll}
\hline \hline & $\begin{array}{c}\text { Great } \\
\text { Buenos Aires }\end{array}$ & Pampa & Northeast & $\begin{array}{c}\text { Northwest } \\
\text { \& Cuyo }\end{array}$ & Patagonia \\
\hline Unskilled & 0.71 & 0.71 & 0.85 & 0.69 & 0.69 \\
& $(0.13)$ & $(0.10)$ & $(0.11)$ & $(0.14)$ & $(0.15)$ \\
SemiSkilled & 0.57 & 0.73 & 0.81 & 0.74 & 0.60 \\
& $(0.12)$ & $(0.10)$ & $(0.15)$ & $(0.18)$ & $(0.19)$ \\
Skilled & 0.82 & 0.84 & 0.58 & 0.74 & 0.41 \\
& $(0.23)$ & $(0.16)$ & $(0.19)$ & $(0.21)$ & $(0.28)$ \\
Trends Unskilled & 0.009 & 0.022 & 0.027 & 0.015 & 0.018 \\
& $(0.008)$ & $(0.004)$ & $(0.005)$ & $(0.006)$ & $(0.009)$ \\
Trends Semiskilled & 0.026 & 0.031 & 0.032 & 0.024 & 0.023 \\
& $(0.006)$ & $(0.004)$ & $(0.005)$ & $(0.007)$ & $(0.007)$ \\
Trends Skilled & 0.038 & 0.041 & 0.047 & 0.036 & 0.027 \\
& $(0.014)$ & $(0.008)$ & $(0.007)$ & $(0.009)$ & $(0.009)$ \\
\hline \hline
\end{tabular}

Notes: cluster-corrected standard errors within parenthesis. Signi cance levels: *, 10 percent; **, 5 percent, $* * *, 1$ percent. The log of wages is regressed on the log of the prices of agricultural exports. The regression includes also a trend interacted with education dummies (to capture technological change), educational dummies, import prices, and individual controls such as age, age squared, marital status and gender dummies.

Table 3. Wage Price Elasticities. Agricultural Export Price 


\begin{tabular}{|c|c|c|c|c|c|}
\hline & \multirow{2}{*}{$\begin{array}{c}\text { Initial } \\
\text { Poverty } \\
\text { Rate } \\
(1)\end{array}$} & \multicolumn{3}{|c|}{ Ex-Post Poverty Rates } & \multirow{2}{*}{$\begin{array}{c}\text { Total } \\
\text { Poverty } \\
\text { Changes } \\
(5)\end{array}$} \\
\hline & & $\begin{array}{l}\text { Adjusting } \\
\text { Poverty line } \\
\text { (2) }\end{array}$ & $\begin{array}{l}\text { Adjusting } \\
\text { Income } \\
\text { (3) }\end{array}$ & $\begin{array}{c}\text { Total } \\
\text { (4) }\end{array}$ & \\
\hline \multicolumn{6}{|c|}{ A) Lower Bound for Price Change } \\
\hline National & 29.26 & 30.46 & 27.56 & 28.80 & -0.46 \\
\hline Buenos Aires & 23.32 & 24.09 & 22.31 & 23.02 & -0.30 \\
\hline Pampa & 27.30 & 28.23 & 25.71 & 26.98 & -0.32 \\
\hline Northeast & 36.36 & 37.77 & 34.00 & 35.50 & -0.86 \\
\hline Northwest & 40.55 & 42.48 & 38.70 & 40.24 & -0.31 \\
\hline Cuyo & 27.48 & 28.95 & 25.53 & 26.78 & -0.70 \\
\hline Patagonia & 18.28 & 19.11 & 17.38 & 18.06 & -0.22 \\
\hline \multicolumn{6}{|c|}{ B) Upper Bound for Price Change } \\
\hline National & 29.26 & 31.30 & 26.38 & 28.28 & -0.98 \\
\hline Buenos Aires & 23.32 & 24.58 & 21.58 & 22.56 & -0.76 \\
\hline Pampa & 27.30 & 29.01 & 24.77 & 26.37 & -0.93 \\
\hline Northeast & 36.36 & 38.88 & 32.07 & 34.74 & -1.62 \\
\hline Northwest & 40.55 & 43.62 & 37.25 & 39.92 & -0.63 \\
\hline Cuyo & 27.48 & 29.89 & 24.32 & 26.25 & -1.23 \\
\hline Patagonia & 18.28 & 19.60 & 16.36 & 17.84 & -0.44 \\
\hline
\end{tabular}

Notes: Poverty impacts of trade liberalization in the developed world. The lower bound for the price change of Argentine exports of agro-manufactures is 7.5 percent; the upper bound is 15.4 percent.

Column (1): initial head count in October 1998 (Indec, 2002).

Column (2): Ex-post poverty rate of allowing adjustments in the poverty line while keeping nominal income constant. Column (3): Ex-post poverty rate of allowing adjustments in nominal wage while keeping the poverty line constant.

Column (4): Ex-post poverty rate of allowing adjustments in the poverty line and in nominal household income.

Column (5): Overall poverty changes (4)-(1).

Table 4. Changes in Poverty following Agricultural Liberalization 


\section{SERIE DOCUMENTOS DE TRABAJO DEL CEDLAS}

Todos los Documentos de Trabajo del CEDLAS están disponibles en formato electrónico en 〈www.depeco.econo.unlp.edu.ar/cedlas〉.

- Nro. 96 (Abril, 2010). Guido Porto. "International Market Access and Poverty in Argentina".

- Nro. 95 (Marzo, 2010). María Laura Alzúa, Guillermo Cruces y Laura Ripani. "Welfare Programs and Labor Supply in Developing Countries. Experimental Evidence from Latin America".

- Nro. 94 (Febrero 2010). Ricardo Bebczuk y Diego Battistón. "Remittances and Life Cycle Deficits in Latin America".

- Nro. 93 (Enero, 2010). Guillermo Cruces, Sebastian Galiani y Susana Kidyba. "Payroll Taxes, Wages and Employment: Identification through Policy Changes".

- Nro. 92 (Diciembre, 2009). Mauricio Zunino. "Impactos de la Reinstauración de los Consejos de Salarios sobre la Distribución Salarial en Uruguay: Conclusiones, Hipótesis e Interrogantes".

- Nro. 91 (Diciembre, 2009). María Laura Alzúa, Catherine Rodriguez y Edgar Villa. "The Quality of Life in Prisons: Do Educational Programs Reduce In-prison Conflicts?".

- Nro. 90 (Noviembre, 2009). Diego Battiston, Guillermo Cruces, Luis Felipe Lopez Calva, Maria Ana Lugo y Maria Emma Santos. "Income and Beyond: Multidimensional Poverty in Six Latin American countries".

- Nro. 89 (Octubre, 2009). Mariana Viollaz, Sergio Olivieri y Javier Alejo. "Labor Income Polarization in Greater Buenos Aires".

- Nro. 88 (Septiembre, 2009). Sebastian Galiani. "Reducing Poverty in Latin America and the Caribbean".

- Nro. 87 (Agosto, 2009). Pablo Gluzmann y Federico Sturzenegger. “An Estimation of CPI Biases in Argentina 1985-2005, and its Implications on Real Income Growth and Income Distribution".

- Nro. 86 (Julio, 2009). Mauricio Gallardo Altamirano. "Estimación de Corte Transversal de la Vulnerabilidad y la Pobreza Potencial de los Hogares en Nicaragua".

- Nro. 85 (Junio, 2009). Rodrigo López-Pablos. "Una Aproximación Antropométrica a la Medición de la Pobreza". 
- Nro. 84 (Mayo, 2009). Maribel Jiménez y Mónica Jiménez. "La Movilidad Intergeneracional del Ingreso: Evidencia para Argentina".

- Nro. 83 (Abril, 2009). Leonardo Gasparini y Pablo Gluzmann "Estimating Income Poverty and Inequality from the Gallup World Poll: The Case of Latin America and the Caribbean".

- Nro. 82 (Marzo, 2009). Facundo Luis Crosta. "Reformas Administrativas y Curriculares: El Efecto de la Ley Federal de Educación sobre el Acceso a Educación Media".

- Nro. 81 (Febrero, 2009). Leonardo Gasparini, Guillermo Cruces, Leopoldo Tornarolli y Mariana Marchionni. "A Turning Point? Recent Developments on Inequality in Latin America and the Caribbean".

- Nro. 80 (Enero, 2009). Ricardo N. Bebczuk. "SME Access to Credit in Guatemala and Nicaragua: Challenging Conventional Wisdom with New Evidence".

- Nro. 79 (Diciembre, 2008). Gabriel Sánchez, María Laura Alzúa e Inés Butler. "Impact of Technical Barriers to Trade on Argentine Exports and Labor Markets".

- Nro. 78 (Noviembre, 2008). Leonardo Gasparini y Guillermo Cruces. "A Distribution in Motion: The Case of Argentina".

- Nro. 77 (Noviembre, 2008). Guillermo Cruces y Leonardo Gasparini. "Programas Sociales en Argentina: Alternativas para la Ampliación de la Cobertura".

- Nro. 76 (Octubre, 2008). Mariana Marchionni y Adriana Conconi. "¿Qué y a Quién? Beneficios y Beneficiarios de los Programas de Transferencias Condicionadas de Ingresos".

- Nro. 75 (Septiembre, 2008). Marcelo Bérgolo y Fedora Carbajal. "Brecha Urbano Rural de Ingresos Laborales en Uruguay para el Año 2006: Una Descomposición por Cuantiles".

- Nro. 74 (Agosto, 2008). Matias D. Cattaneo, Sebastian Galiani, Paul J. Gertler, Sebastian Martinez y Rocio Titiunik. "Housing, Health and Happiness".

- Nro. 73 (Agosto, 2008). María Laura Alzúa. "Are Informal Workers Secondary Workers?: Evidence for Argentina".

- Nro. 72 (Julio, 2008). Carolina Díaz-Bonilla, Hans Lofgren y Martín Cicowiez. "Public Policies for the MDGs: The Case of the Dominican Republic".

- Nro. 71 (Julio, 2008). Leonardo Gasparini, Facundo Crosta, Francisco Haimovich, Beatriz Alvarez, Andrés Ham y Raúl Sánchez. "Un Piso de Protección Social en América Latina: Costos Fiscales e Impactos Sociales".

- Nro. 70 (Junio, 2008). Mariana Viollaz. "Polarización de ingresos laborales: Argentina 1992-2006". 
- Nro. 69 (Mayo, 2008). Mariana Marchionni, Walter Sosa Escudero y Javier Alejo. "Efectos Distributivos de Esquemas Alternativos de Tarifas Sociales: Una Exploración Cuantitativa".

- Nro. 68 (Mayo, 2008). Ricardo N. Bebczuk. "Financial Inclusion in Latin America and the Caribbean: Review and Lessons".

- Nro. 67 (Abril, 2008). Mariana Marchionni, Walter Sosa Escudero y Javier Alejo. "La Incidencia Distributiva del Acceso, Gasto y Consumo de los Servicios Públicos".

- Nro. 66 (Abril, 2008). Ricardo N. Bebczuk. "Dolarización y Pobreza en Ecuador".

- Nro. 65 (Marzo, 2008). Walter Sosa Escudero and Anil K. Bera. "Tests for Unbalanced Error Component Models Under Local Misspecication".

- Nro. 64 (Febrero, 2008). Luis Casanova. "Trampas de Pobreza en Argentina: Evidencia Empírica a Partir de un Pseudo Panel".

- Nro. 63 (Enero, 2008). Francisco Franchetti y Diego Battistón. "Inequality in Health Coverage, Empirical Analysis with Microdata for Argentina 2006".

- Nro. 62 (Diciembre, 2007). Adriana Conconi, Guillermo Cruces, Sergio Olivieri y Raúl Sánchez. "E pur si muove? Movilidad, Pobreza y Desigualdad en América Latina".

- Nro. 61 (Diciembre, 2007). Mariana Marchionni, Germán Bet y Ana Pacheco. "Empleo, Educación y Entorno Social de los Jóvenes: Una Nueva Fuente de Información".

- Nro. 60 (Noviembre, 2007). María Gabriela Farfán y María Florencia Ruiz Díaz. "Discriminación Salarial en la Argentina: Un Análisis Distributivo".

- Nro. 59 (Octubre, 2007). Leopoldo Tornarolli y Adriana Conconi. "Informalidad y Movilidad Laboral: Un Análisis Empírico para Argentina".

- Nro. 58 (Septiembre, 2007). Leopoldo Tornarolli. "Metodología para el Análisis de la Pobreza Rural".

- Nro. 57 (Agosto, 2007). Adriana Conconi y Andrés Ham. "Pobreza Multidimensional Relativa: Una Aplicación a la Argentina".

- Nro. 56 (Agosto, 2007). Martín Cicowiez, Luciano Di Gresia y Leonardo Gasparini. "Politicas Públicas y Objetivos de Desarrollo del Milenio en la Argentina".

- Nro. 55 (Julio, 2007). Leonardo Gasparini, Javier Alejo, Francisco Haimovich, Sergio Olivieri y Leopoldo Tornarolli. "Poverty among the Elderly in Latin America and the Caribbean". 
- Nro. 54 (Julio, 2007). Gustavo Javier Canavire-Bacarreza y Luís Fernando Lima Soria. "Unemployment Duration and Labor Mobility in Argentina: A Socioeconomic-Based Pre- and Post-Crisis Analysis".

- Nro. 53 (Junio, 2007). Leonardo Gasparini, Francisco Haimovich y Sergio Olivieri. "Labor Informality Effects of a Poverty-Alleviation Program".

- Nro. 52 (Junio, 2007). Nicolás Epele y Victoria Dowbley. "Análisis Ex-Ante de un Aumento en la Dotación de Capital Humano: El Caso del Plan Familias de Transferencias Condicionadas".

- Nro. 51 (Mayo, 2007). Jerónimo Carballo y María Bongiorno. "Vulnerabilidad Individual: Evolución, Diferencias Regionales e Impacto de la Crisis. Argentina 1995 - 2005".

- Nro. 50 (Mayo, 2007). Paula Giovagnoli. "Failures in School Progression".

- Nro. 49 (Abril, 2007). Sebastian Galiani, Daniel Heymann, Carlos Dabús y Fernando Tohmé. "Land-Rich Economies, Education and Economic Development".

- Nro. 48 (Abril, 2007). Ricardo Bebczuk y Francisco Haimovich. "MDGs and Microcredit: An Empirical Evaluation for Latin American Countries".

- Nro. 47 (Marzo, 2007). Sebastian Galiani y Federico Weinschelbaum. "Modeling Informality Formally: Households and Firms".

- Nro. 46 (Febrero, 2007). Leonardo Gasparini y Leopoldo Tornarolli. "Labor Informality in Latin America and the Caribbean: Patterns and Trends from Household Survey Microdata".

- Nro. 45 (Enero, 2007). Georgina Pizzolitto. "Curvas de Engel de Alimentos, Preferencias Heterogéneas y Características Demográficas de los Hogares: Estimaciones para Argentina".

- Nro. 44 (Diciembre, 2006). Rafael Di Tella, Sebastian Galiani y Ernesto Schargrodsky. "Crime Distribution and Victim Behavior during a Crime Wave".

- Nro. 43 (Noviembre, 2006). Martín Cicowiez, Leonardo Gasparini, Federico Gutiérrez y Leopoldo Tornarolli. "Areas Rurales y Objetivos de Desarrollo del Milenio en America Latina y El Caribe".

- Nro. 42 (Octubre, 2006). Martín Guzmán y Ezequiel Molina. "Desigualdad e Instituciones en una Dimensión Intertemporal".

- Nro. 41 (Septiembre, 2006). Leonardo Gasparini y Ezequiel Molina. "Income Distribution, Institutions and Conflicts: An Exploratory Analysis for Latin America and the Caribbean".

- Nro. 40 (Agosto, 2006). Leonardo Lucchetti. "Caracterización de la Percepción del Bienestar y Cálculo de la Línea de Pobreza Subjetiva en Argentina". 
- Nro. 39 (Julio, 2006). Héctor Zacaria y Juan Ignacio Zoloa. "Desigualdad y Pobreza entre las Regiones Argentinas: Un Análisis de Microdescomposiciones".

- Nro. 38 (Julio, 2006). Leonardo Gasparini, Matías Horenstein y Sergio Olivieri. "Economic Polarisation in Latin America and the Caribbean: What do Household Surveys Tell Us?".

- Nro. 37 (Junio, 2006). Walter Sosa-Escudero, Mariana Marchionni y Omar Arias. "Sources of Income Persistence: Evidence from Rural El Salvador".

- Nro. 36 (Mayo, 2006). Javier Alejo. "Desigualdad Salarial en el Gran Buenos Aires: Una Aplicación de Regresión por Cuantiles en Microdescomposiciones".

- Nro. 35 (Abril, 2006). Jerónimo Carballo y María Bongiorno. "La Evolución de la Pobreza en Argentina: Crónica, Transitoria, Diferencias Regionales y Determinantes (1995-2003)".

- Nro. 34 (Marzo, 2006). Francisco Haimovich, Hernán Winkler y Leonardo Gasparini. "Distribución del Ingreso en América Latina: Explorando las Diferencias entre Países".

- Nro. 33 (Febrero, 2006). Nicolás Parlamento y Ernesto Salinardi. "Explicando los Cambios en la Desigualdad: Son Estadísticamente Significativas las Microsimulaciones? Una Aplicación para el Gran Buenos Aires".

- Nro. 32 (Enero, 2006). Rodrigo González. "Distribución de la Prima Salarial del Sector Público en Argentina".

- Nro. 31 (Enero, 2006). Luis Casanova. "Análisis estático y dinámico de la pobreza en Argentina: Evidencia Empírica para el Periodo 1998-2002".

- Nro. 30 (Diciembre, 2005). Leonardo Gasparini, Federico Gutiérrez y Leopoldo Tornarolli. "Growth and Income Poverty in Latin America and the Caribbean: Evidence from Household Surveys".

- Nro. 29 (Noviembre, 2005). Mariana Marchionni. "Labor Participation and Earnings for Young Women in Argentina".

- Nro. 28 (Octubre, 2005). Martín Tetaz. "Educación y Mercado de Trabajo".

- Nro. 27 (Septiembre, 2005). Matías Busso, Martín Cicowiez y Leonardo Gasparini. "Ethnicity and the Millennium Development Goals in Latin America and the Caribbean".

- Nro. 26 (Agosto, 2005). Hernán Winkler. "Monitoring the Socio-Economic Conditions in Uruguay".

- Nro. 25 (Julio, 2005). Leonardo Gasparini, Federico Gutiérrez y Guido G. Porto. "Trade and Labor Outcomes in Latin America's Rural Areas: A Cross-Household Surveys Approach". 
- Nro. 24 (Junio, 2005). Francisco Haimovich y Hernán Winkler. "Pobreza Rural y Urbana en Argentina: Un Análisis de Descomposiciones".

- Nro. 23 (Mayo, 2005). Leonardo Gasparini y Martín Cicowiez. "Meeting the Poverty-Reduction MDG in the Southern Cone".

- Nro. 22 (Abril, 2005). Leonardo Gasparini y Santiago Pinto. "Equality of Opportunity and Optimal Cash and In-Kind Policies".

- Nro. 21 (Abril, 2005). Matías Busso, Federico Cerimedo y Martín Cicowiez. "Pobreza, Crecimiento y Desigualdad: Descifrando la Última Década en Argentina".

- Nro. 20 (Marzo, 2005). Georgina Pizzolitto. "Poverty and Inequality in Chile: Methodological Issues and a Literature Review".

- Nro. 19 (Marzo, 2005). Paula Giovagnoli, Georgina Pizzolitto y Julieta Trías. "Monitoring the Socio-Economic Conditions in Chile".

- Nro. 18 (Febrero, 2005). Leonardo Gasparini. "Assessing Benefit-Incidence Results Using Decompositions: The Case of Health Policy in Argentina".

- Nro. 17 (Enero, 2005). Leonardo Gasparini. "Protección Social y Empleo en América Latina: Estudio sobre la Base de Encuestas de Hogares".

- Nro. 16 (Diciembre, 2004). Evelyn Vezza. "Poder de Mercado en las Profesiones Autorreguladas: El Desempeño Médico en Argentina".

- Nro. 15 (Noviembre, 2004). Matías Horenstein y Sergio Olivieri. "Polarización del Ingreso en la Argentina: Teoría y Aplicación de la Polarización Pura del Ingreso".

- Nro. 14 (Octubre, 2004). Leonardo Gasparini y Walter Sosa Escudero. "Implicit Rents from Own-Housing and Income Distribution: Econometric Estimates for Greater Buenos Aires".

- Nro. 13 (Septiembre, 2004). Monserrat Bustelo. "Caracterización de los Cambios en la Desigualdad y la Pobreza en Argentina Haciendo Uso de Técnicas de Descomposiciones Microeconometricas (1992-2001)".

- Nro. 12 (Agosto, 2004). Leonardo Gasparini, Martín Cicowiez, Federico Gutiérrez y Mariana Marchionni. "Simulating Income Distribution Changes in Bolivia: a Microeconometric Approach".

- Nro. 11 (Julio, 2004). Federico H. Gutierrez. "Dinámica Salarial y Ocupacional: Análisis de Panel para Argentina 1998-2002".

- Nro. 10 (Junio, 2004). María Victoria Fazio. "Incidencia de las Horas Trabajadas en el Rendimiento Académico de Estudiantes Universitarios Argentinos".

- Nro. 9 (Mayo, 2004). Julieta Trías. "Determinantes de la Utilización de los Servicios de Salud: El Caso de los Niños en la Argentina". 
- Nro. 8 (Abril, 2004). Federico Cerimedo. "Duración del Desempleo y Ciclo Económico en la Argentina".

- Nro. 7 (Marzo, 2004). Monserrat Bustelo y Leonardo Lucchetti. "La Pobreza en Argentina: Perfil, Evolución y Determinantes Profundos (1996, 1998 Y 2001)".

- Nro. 6 (Febrero, 2004). Hernán Winkler. "Estructura de Edades de la Fuerza Laboral y Distribución del Ingreso: Un Análisis Empírico para la Argentina".

- Nro. 5 (Enero, 2004). Pablo Acosta y Leonardo Gasparini. "Capital Accumulation, Trade Liberalization and Rising Wage Inequality: The Case of Argentina".

- Nro. 4 (Diciembre, 2003). Mariana Marchionni y Leonardo Gasparini. "Tracing Out the Effects of Demographic Changes on the Income Distribution. The Case of Greater Buenos Aires".

- Nro. 3 (Noviembre, 2003). Martín Cicowiez. "Comercio y Desigualdad Salarial en Argentina: Un Enfoque de Equilibrio General Computado".

- Nro. 2 (Octubre, 2003). Leonardo Gasparini. "Income Inequality in Latin America and the Caribbean: Evidence from Household Surveys".

- Nro. 1 (Septiembre, 2003). Leonardo Gasparini. "Argentina's Distributional Failure: The Role of Integration and Public Policies". 